$9-2020$

\title{
Why Denominations Can Climb Hills: RLDS Conversions in Highland Tribal India and Midwestern America, 1964-2000
}

David Howlett

Smith College,dhowlett@smith.edu

Follow this and additional works at: https://scholarworks.smith.edu/rel_facpubs

Part of the Religion Commons

\section{Recommended Citation}

Howlett, David, "Why Denominations Can Climb Hills: RLDS Conversions in Highland Tribal India and Midwestern America, 1964-2000" (2020). Religion: Faculty Publications, Smith College, Northampton, MA.

https://scholarworks.smith.edu/rel_facpubs/22

This Article has been accepted for inclusion in Religion: Faculty Publications by an authorized administrator of Smith ScholarWorks. For more information, please contact scholarworks@smith.edu 


\title{
Why Denominations Can Climb Hills: RLDS Conversions in Highland Tribal India and Midwestern America, 1964-2000
}

\author{
David J. Howlett* \\ Mellon Visiting Assistant Professor in the Religion Department at Smith College \\ *Corresponding author. Email: dhowlett@smith.edu
}

Based on oral history interviews and archival sources, this essay analyzes the religious affiliation between Sora villagers in the highlands of eastern India with Reorganized Church of Jesus Christ of Latter Day Saints (RLDS) members in the American Midwest. The relationship between these distinct groups transposed a pattern of interactions between highlands and lowlands in upland Asia to a new globalized space in the late twentieth century. Conceiving of "conversion" as a broad analytic trope to discuss various individual, group, and organizational transformations, this essay argues that "converts" in the Sora highlands and American plains instrumentalized their relationships with the other for their own ends. In the Americans, the Sora found a new patron for long-standing client-patron relationships between highlands people and valley people. In the Sora, the Americans found an "indigenous other" who could be used to justify reforms within their local church body along more cosmopolitan lines. As an upshot of these interactions, Sora and Americans effectively reterritorialized older patterns of "hills" and "valleys" that had been deterritorialized by state-sponsored modernization. Thus, the hills and valleys of upland Asia found a surprising afterlife within the space of a global Christian denomination.

Keywords: Globalization and Religion; Religious Conversion; India and the United States; RLDS Church; India - Scheduled Tribes

In the late 1960s, Baidi Mandal joined a church based in the United States. Mandal and her husband lived in a Lanjia Sora tribal village in the highlands of Orissa (present day Odisha), India, and like other Sora, their family practiced frequent ritualized communication with their ancestors. The Mandals broke with this tradition and were baptized by a traveling Sora missionary sponsored by a church from the American Midwest, the Reorganized Church of Jesus Christ of Latter Day Saints (RLDS). In response to the Mandals' conversion, their fellow villagers began to harass them by throwing stones at their house. Finally, the village leaders came to their home and forcibly removed the husband, declaring that they were going to execute him. "They took my husband, but it was not God's will, and they did not kill him," Mandal relayed through a Sora interpreter. "They thought when we become Christian, we are the Dalit people, the untouched people, but after [three years] all [the] village would become 
Christian."1 The Sora in Mandal's village initially feared that Christian conversion would fundamentally alter their identities and place them on the bottom of a Hindu caste schema that the village had assiduously remained outside as "tribal" people. ${ }^{2}$ Despite these fears, the entire village joined the RLDS Church within three years. Thousands in nearby Sora villages had also done so by the 1980s.

Half a world away, RLDS members in the American Midwest were debating policies about Sora conversions. In 1967, the Council of Twelve Apostles, who administer the church's various jurisdictions and missions, allowed for the baptism of polygamous Sora, with the caveat that a baptized individual could not enter into future polygamous unions. The nineteenth-century RLDS Church, founded by Mormon dissenters in the American Midwest, had categorically opposed the polygamous marriages practiced by their Latter-day Saints (LDS) ecclesiastical cousins. ${ }^{3}$ Yet, by the 1970s, the church's American leaders had begun to embrace a paradigm of cultural pluralism and, thus, were seeking a qualified acceptance of polygamy, at least among people outside of the United States. The American RLDS leaders did so by appeals to theologies of indigenization, drawn from ecumenical Protestants. In response, a significant minority of American RLDS church members feared that the Sora conversion policy and its justifications revealed a growing and worrisome liberalism within their church. These church members believed that their church was losing its distinct identity, an identity that conservatives saw tied to a universal "restored gospel" to which all peoples had to conform. Still, the majority of American church members voted to accept the Sora conversion policy in 1972, and many marked the debate as a watershed moment in the transformation-perhaps even conversion-of their Midwestern American-based church along more cosmopolitan lines.

\footnotetext{
${ }^{1}$ Baidi Mandal, interview with the author, Badakua, Odisha, 28 June 2014. For direct quotes, I have relied upon the English translation by a Sora pastor who accompanied me during my time in Odisha. His translations often preserve the "parallel doublets" in Sora sentence structure where a thought is said and then repeated a second time with a slight difference to emphasize the statement. See Piers Vitebsky, Living without the Dead: Loss and Redemption in a Jungle Cosmos (Chicago: University of Chicago Press, 2017), 3-4.

${ }^{2}$ Throughout this essay, I use terms like "Scheduled Tribe," "tribal," "Scheduled Caste," and "Dalit." The term Scheduled Tribe is enshrined in the Indian Constitution and was later controversially defined by the Indian union government's Lokur Committee (1965) as a group that has "(a) indications of primitive traits; (b) distinctive culture; (c) shyness of contact with the community at large; (d) geographical isolation; and (e) backwardness." The term "tribal" is both an emic term (one used by my interviewees for themselves) and an etic shorthand term used by many scholars for groups recognized by the Indian government as Scheduled Tribes. In recent decades, various rights groups in India have advocated for identifying Scheduled Tribes as adivāsis ("indigenous peoples"). However, this term was unfamiliar to all of my Scheduled Tribe interview partners. Scheduled Castes is the Indian government's term for groups deemed outside of the various varna (class) schemas of the colonial era. In particular, "Scheduled Castes" were the so-called "untouchables," referred to by Gandhi as harijans ("children of god"). Today, many Scheduled Caste people identify with the term "Dalit," a term coined by the Indian leader B. R. Ambedkar that means "the crushed" or "the oppressed." My interview partners used both Scheduled Caste and Dalit to describe their nontribal, noncaste neighbors. For more information, see Nandini Sundar, "Introduction: Of the Scheduled Tribes, States, and Sociology," in The Scheduled Tribes and Their India: Politics, Identities, Policies, and Work, ed. Nandini Sundar (New York: Oxford University Press, 2016), 1-7; and Robert Eric Frykenberg, Christianity in India: From Beginnings to the Present (New York: Oxford University Press, 2008), 48.

${ }^{3}$ Roger D. Launius, Joseph Smith III: Pragmatic Prophet (Urbana: University of Illinois Press, 1988), 140159, 190-209.
} 
Sora conversions and American debates on conversion occurred at the cusp of "globalization." Scholars have often framed globalization as not simply the flow of ideologies, goods, and practices across vast spaces-something that has happened for millenniabut the mid-to-late twentieth-century amplification of international political, economic, and cultural processes or, as one classic definition states, "the compression of the world and the intensification of the consciousness of the world as a whole." ${ }^{4}$ In an era of globalization, conversion in a rural Sora village was not simply an intra-village dispute. What happened in a Sora highland village could affect what happened in an American Midwestern denomination and vice versa. Framed in another way: what happened in the hills impacted the plains, and the plains reshaped the hills.

Thinking of the intra-Sora conversion controversies in this manner is a nod to James C. Scott's study of the interactions between "hills" and "valleys" in pre-twentieth century upland Asia. In a frequent talk, "Why Civilizations Can't Climb Hills," which he later expanded into the book The Art of Not Being Governed: An Anarchist History of Upland Southeast Asia, Scott asserts that highland peoples fled to the hills from rice cultivating states and thereby avoided becoming part of the primordial civilizational building blocks out of which the valley civilizations emerged. Over the course of several centuries, highland peoples created "non-state" spaces that effectively resisted successive state attempts to bring them within its domain. Highland peoples did this through conscious strategies of resistance, such as losing their written languages and becoming "illegible" to the state, practicing swidden agriculture and thus refusing to remain settled, and resisting taxation. Seen in this way, the hills themselves were a "state effect" constituted by people reacting to and seeking to escape from the state. A valley culture, too, could be thought of as a "hill effect," as people from diverse groups gathered into the valleys; constructed themselves from "many cultural shards" into a flattened, taxable, and legible group; and were "at pains to distinguish their culture from populations outside the state," especially the people of the hills who were beyond the state. ${ }^{5}$ Valley people and hill people, then, mutually constituted each other.

Scott's work ignited intense interest and, like most influential works, intense criticism from a wide array of scholars. If there was a scholarly consensus that emerged, it was that Scott provided a startlingly innovative way of thinking about the uplands of Asia rather than providing a precise history of the region. ${ }^{6}$ Applying this general consensus, I argue that Scott's suggestive work provides a useful starting point for thinking about a related but distinctly different occurrence: Christian denominations and their global connections. If states have historically failed "to climb hills," as Scott asserts, how has it been that Christian denominations, like the American RLDS, have been so successful at doing so? Why would highland people, like the Sora, want to convert

\footnotetext{
${ }^{4}$ Roland Robertson, Globalization: Social Theory and Global Culture (Thousand Oaks, Calif.: SAGE, 1992), 8.

${ }^{5}$ James C. Scott, The Art of Not Being Governed: An Anarchist History of Upland Southeast Asia (New Haven, Conn.: Yale University Press, 2009), 24, 28.

${ }^{6}$ Tom Brass, “Scott's 'Zomia' or a Populist Post-modern History of Nowhere," Journal of Contemporary Asia 42, no. 1 (February 2012): 122-133; Bengt G. Karlsson, "Evading the State: Ethnicity in Northeast India through the Lens of James Scott," in "Performing Identity Politics and Culture in Northeast India and Beyond," special issue, Asian Ethnology 72, no. 2 (2013): 321-331; and Michael R. Dove, Hjorleifur Jonsson, and Michael Aung-Thwin, "Debate," forum on The Art of Not Being Governed: An Anarchist History of Upland Southeast Asia, by James C. Scott, Bijdragen tot de Taal-, Land-en Volkenkunde 167, no. 1 (2011): 86-99.
} 
in the first place? And what does the denomination's act of climbing the hills do for both parties?

These questions might elicit rather straightforward answers. Scott asserts that the physical and ideological separation of hill peoples versus valley peoples resulted in religious practices distinct from each other. In contrast to the Hinduism and Buddhism of valley peoples, the hill peoples of upland Asia often practiced some form of localized animism before the nineteenth century or Christianity in the twentieth century. ${ }^{7}$ In this sense, the hill peoples' conversions to Christianity reinforced a consistently maintained boundary. Similarly, we might simply observe that many twentieth-century Protestant denominations were evangelizing groups, and climbing hills made theological sense to them. The American RLDS simply followed a long-established Protestant pattern of going "into all the world." Whatever the validity of these arguments, they stop short of asking how hills and valleys have been reconfigured in the resulting relationships, as well as how evangelizing the highlands functions for the denomination that established its presence in the hills. Additionally, such answers fail to consider how the social processes of globalization have provided new possibilities for the restructuring of hills and valleys.

This essay offers a case study of late twentieth-century interactions between the highlands of Sora tribal India with the plains of a Midwestern-based American Mormon denomination, a case study of hills and valleys in a globalized world. As my beginning anecdotes suggest, the 1960s were a time of astounding transformations within Sora tribal villages and American-based RLDS congregations and conferences. Through oral history interviews and archival sources, this essay will track these changes from 1964 to 2000, a time through which a new generation of Sora and Americans rose to leadership roles in the RLDS church. Much of this essay will focus on "conversions" in the hills and the valleys of Eastern India, with "conversion" serving as a broad analytic trope to discuss various individual, group, and organizational transformations. ${ }^{8}$ In so doing, this essay details how the highlands/lowlands division in Soraland has had a life beyond the mere contiguous geography of upland Asia.

This last point offers a direct rejoinder to Scott, who ended his analysis well before the story that I narrate took place. Scott claims that state forces, aided by "technological prowess and sovereign ambitions" after World War II, brought the non-state spaces of the highlands into the legible, disciplined, taxable domain of the valley. The contemporary world has entered an "era in which virtually the entire globe is 'administered space," Scott laments, "and the periphery is not much more than a folkloric remnant." Yet Asian studies scholar Michael Dove perceptively argues that Scott "severely limitsperhaps overly so-the applicability and relevance of his analysis." Dove goes on to posit areas where Scott's examination of "state effects and secondary barbarism" might apply today, such as in the "emergence of back-to-the-land social movements, drug cartel territories, and even virtual realities." ${ }^{\prime 0}$ To Dove's list, I would add global denominations, structures that can contain within them state and non-state spaces.

\footnotetext{
${ }^{7}$ Scott, Art of Not Being Governed, 21.

${ }^{8}$ Dennis Washburn and A. Kevin Reinhart, "Introduction" to Converting Cultures: Religion, Ideology, and Transformations of Modernity, ed. Dennis Washburn and A. Kevin Reinhart (Leiden: Brill, 2007), xiv.

${ }^{9}$ Scott, Art of Not Being Governed, 325.

${ }^{10}$ Michael R. Dove, "Escaping the State? Scott on Southeast Asia," in "Debate," book forum on The Art of Not Being Governed, 90.
} 
The American RLDS Church in particular functioned in select ways like a state through its ambitions to reshape the Sora hills with development projects (schools and clinics), juridical powers (church discipline and church courts), a common ideology (beliefs about humans and the cosmos), organizational schemas for local authority (ordained and lay officials), and a standardization of the means of what Scott called "legibility" (systems of measurement and recording). Like many state actors before it, the American RLDS Church found that the Sora highlands were resistant to some of these changes, particularly changes to local authority structures and localized ideologies. This very resistance was facilitated by the "state" ideology that drove the American RLDS to expand into the Sora highlands.

Mid-twentieth-century American RLDS missionaries and leaders embraced a missiology of indigenization: they assumed that a new mission was best led by local indigenous leaders and that once the "seed of the gospel" was planted, a local church would grow up as a localized manifestation of a universal church. Such a missiological formulation was drawn almost directly from currents in mid-twentieth-century Protestant missiology, which had their roots in mid-nineteenth-century missiological theory, as will become clear below. ${ }^{11}$ Yet it was also reflective of a wider American political project. As Sarah Ruble has perceptively argued, indigenization paralleled what some scholars have termed the ideology of political Wilsonianism, an American foreign policy ideology which held that peoples across the world should be allowed to pursue a path of national selfdetermination in terms of governance-that is, as long as that self-determination manifested itself as a democratic state. ${ }^{12}$ Through advocacy for indigenization, the American RLDS took the Wilsonian political project into the realm of relationships within their denomination. The global political system here was the RLDS Church itself, and the nation states vying for self-determination were the converts that the American RLDS grouped according to "cultures" into "national churches," like the Sora RLDS Church. Like the American standard-bearers of the Wilsonian project who could not resist telling other nations what self-determination should look like, the American RLDS indigenizers could not resist trying to shape Sora self-determination.

Nevertheless, the Sora creatively seized the opportunity to affiliate with the American church for their own ends. By doing so, they aspired to disentangle themselves from what Sora converts saw as exploitative economic and political relationships between the Sora hills and the Hindu valleys of eastern India. For these Sora, the American RLDS Church provided a gentler version of the state than the Hindu valley. Furthermore, the new Sora RLDS Church successfully resisted various standardizing schemas of the American RLDS "state" and, in so doing, functionally recreated a nonstate space in Soraland. Thus the Sora RLDS and the American RLDS transposed earlier relationships of highlands and lowlands to a new global flow-the global denomination.

\section{The Twentieth-Century Sora Highlands before Christianity}

Living in the eastern Indian states of Odisha (Orissa) and Andhra Pradesh, the Sora (also spelled Savara and Saora in some sources) are a "tribal" people numbering approximately 300,000 today. The Lanjia Sora, a subdivision of the larger grouping of Sora-speaking peoples, mainly live in the hill country of the Eastern Ghats in southern

\footnotetext{
${ }^{11}$ Dana L. Robert, "Forty Years of North American Missiology: A Brief Review," International Bulletin of Missionary Research 38, no. 1 (January 2014): 4.

${ }^{12}$ Sarah E. Ruble, The Gospel of Freedom and Power: Protestant Missionaries in American Culture after World War II (Chapel Hill: University of North Carolina Press, 2012), 6-9.
} 
Odisha. ${ }^{13}$ In the 1940 s, most Lanjia Sora lived in relative isolation from the structures of the Indian nation state and occupied small villages of eighty to six hundred people where they cultivated rice in small terraced paddies or practiced shifting agriculture on the hillsides. The ancestors spoke to the Sora almost daily through Sora ritual specialists who channeled the spirits of the dead. These ancestors required sacrificial offerings to slake their hunger, or else they could be dangerous and afflict the living with illness or death. The major transition periods of life-transitions that continue to occur beyond mortal death as ancestors were believed to evolve into new formsrequired sacrifices of chickens, pigs, or water buffalo. Sora villagers could go into deep debt for these life events, relying on valley-dwelling Pano-caste traders to finance major sacrificial offerings at high interest rates. ${ }^{14} \mathrm{~A}$ relationship of both mutual reliance and mutual contempt existed between these two groups.

By the mid-twentieth century, the Lanjia Sora increasingly navigated state-sponsored modernization efforts that brought government police stations, schools, and roads ever closer to them, along with changes in the power of the state to reform, discipline, and punish their physical, corporeal bodies. The Sora witnessed the first police station arrive in their region in 1950, followed by roads to some of their villages in the 1970s, and electricity in select locations by $2007 .{ }^{15}$ Kurans, Sora ritual specialists, channeled the spirits of the dead and incorporated some of these social developments into their cosmology: kurans married high-caste Hindus in the spirit world who were said to be judges and police officers; kurans asserted that these spirit-spouses could "handcuff" spirits who afflicted the living and bring the offending spirits to a dialogue with them; kurans, though they were illiterate, recorded messages from the dead by imitating the Oriya-script writing of the valley people. ${ }^{16}$ While these adaptations allowed some Sora to extend their traditional sacred canopies to envelop various forms of state-sponsored modernization, other Sora began fashioning an entirely new sacred canopy. Some Sora began to convert to Christianity.

\section{Sora Conversion Patterns and the Reinvention of Sora Identity}

In 1959, Sora from southern Orissa who had been converted by Canadian Baptist missionaries began to evangelize villages in the Mohana block of Ganjam district, Orissa. By 1960, the first Christian convert among these Sora had been made. ${ }^{17}$ At the same time in the coastal city of Berhampur (Brahmapur), Gurbaksh Singh (G. S.) Chawla (a Sikh-turned-Baptist) and Junesh Raika (a Sora Baptist minister) wrote to the

\footnotetext{
${ }^{13}$ Piers Vitebsky, "Stones, Shamans, and Pastors: Pagan and Baptist Temporalities of Death in Tribal India," in Taming Time, Timing Death: Social Technologies and Ritual, ed. Dorthe Reflund Christensen and Raine Willerslev (New York: Routledge, 2013), 120; and Vitebsky, Living without the Dead, 9.

${ }^{14}$ Piers Vitebsky, Dialogues with the Dead: The Discussion of Mortality among the Sora of Eastern India (Cambridge: Cambridge University Press, 1993), 5; Vitebsky, Living without the Dead, 8-9, 21-22, 29-31; and Jacob Gamanga, interview, Mutaguda, Odisha, 22 June 2014.

${ }^{15}$ Birsuna Mandal, email to author, 2 July 2017; and Georg Pfeffer, “Times of Trouble for Christians in Muslim and Hindu Societies of South Asia," in Constructing Indian Christianities: Culture, Conversion and Caste, ed. Chad M. Bauman and Richard Fox Young (New York: Routledge, 2014), 172.

${ }^{16}$ Vitebsky, "Stones, Shamans, and Pastors," 127-128; Vitebsky, Living without the Dead, 1, 64-65; and Birsuna Mandal, email to author.

${ }^{17}$ Orville E. Daniel, Moving with the Times: The Story of Baptist Outreach from Canada into Asia, South America, and Africa, During One Hundred Years, 1874-1974 (Toronto: Canadian Baptist Overseas Mission Board, 1973), 159; and Birsuna Mandal, "A Brief History of Community of Christ East India Mission in East Odisha," translated by Jyotshna Rai Gamanga (unpublished manuscript, 2014), 2.
} 
RLDS Church in the United States and sought sponsorship for a mission to Sora villages in the Ganjam hills. Chawla and Raika were religious entrepreneurs and had written to several churches, but only the RLDS Church sent individuals to investigate their request. After a series of meetings near Berhampur in 1965 with American RLDS apostles (members of the highest missionary group in the church), Chawla and Raika were baptized and ordained in the RLDS Church. With funding from the American-based church, Chawla, Raika, and a nineteen-year-old former Baptist from Andhra Pradesh named Ananda Rao pursued their mission to Sora villages, establishing a rudimentary church-sponsored school and a basic medical clinic by the late 1960s. ${ }^{18}$

The American reliance on missionaries like Chawla, Raika, and Rao was shaped by larger circumstances beyond the mission itself. By the mid-1960s, many North American and European denominations in India were withdrawing their full-time foreign missionaries and turning their missions over to independent control by indigenous leaders. This was in response to changing attitudes among ecumenical Protestants toward missionary work in general, as well as rising anti-Christian missionary sentiments among emergent Hindutva movements who sent their own missionaries to reconvert tribal peoples. In addition, the government of India issued fewer and fewer work visas for foreign Christian missionaries. For example, the Canadian Baptist missionaries who evangelized the Sora in southern Orissa found obtaining work visas was nearly impossible and began to leave India in the late 1960s. All full-time Canadian Baptist missionaries were gone by the end of the 1970s. Thus, out of principle and practical necessity, the American RLDS had to rely on missionary employees like Chawla, Raika, and Rao to manage all day-to-day supervision of the emerging Sora mission. ${ }^{19}$

Given these circumstances, American RLDS missionaries, individuals higher up in the RLDS hierarchy than Chawla and Raika, traveled to India on tourist visas and visited Soraland only episodically, staying in villages for a few days or a few weeks during their yearly tours of RLDS groups in South and East Asia. On their tours of Soraland, the American missionaries might baptize Sora, ordain them, and attend Sora church conferences, but unlike their missions to Japan and Korea, they did not stay for any extended periods of time. ${ }^{20}$ As I will note later, American RLDS missionaries initially accommodated the forms of Christianity that emerged in Soraland, even though these forms differed greatly from the American RLDS Church. Such an approach proved relatively successful for church growth and gave the emerging Sora congregations far greater autonomy than American congregations in the same era.

By the 1970s, more than a dozen RLDS Sora congregations had emerged in Ganjam district, Orissa. In a few instances, entire villages converted to the RLDS Church en masse, but most Sora converted one family at a time, slowly changing the religious landscape of

\footnotetext{
${ }^{18}$ Gurbaksh Singh (G. S.) Chawla to Donald O. Chesworth, Berhampur, Orissa, 23 October 1962, “Chawla, G. S. (India), 1961-1972,” First Presidency Papers, RG29-1, Community of Christ Archives, Independence, Mo. (hereafter cited as CCA); G. S. Chawla to the Saints in Central Council Bluffs Congregation, 1 March 1968, Roy A. Cheville Papers, f198, CCA; Birsuna Mandal, "Brief History," 2-4; and Charles D. Neff to Presiding Bishopric, Independence, Mo., 29 July 1969, Presiding Bishopric Papers, RG 28, f53, CCA.

${ }^{19}$ Brian Stanley, Christianity in the Twentieth Century: A World History (Princeton, N.J.: Princeton University Press, 2018), 194-196; Pralay Kanungo, “Hindutva's Entry into a 'Hindu Province': Early Years of RSS in Orissa," Economic and Political Weekly 38, no. 1 (2003): 3299-3300; Kenneth Knight and Shirley Knight, The Seed Holds the Tree: A Story of the Kingdom of God in India (n.p., 2009), $193-194$.

${ }^{20}$ "Neff and Cole Return from Orient," Saints' Herald 113, 1 February 1966, 75; and “Apostle Neff Returns from India," Saints' Herald 113, 15 November 1966, 786.
} 
their villages over a period of years, or even decades, until whole villages claimed Christianity as their religion. ${ }^{21}$ In the oral histories I collected from early Sora converts, individuals frequently cited the end of costly animal sacrifices for healing as one of the principle attractions of Christianity. For example, Kando Sabaro, speaking from memory about the late 1970s, reported: "I used to offer the animal sacrifice. And then because of that, I became landless, and I sold everything like gold, like land, I sold to others. And then I became helpless. ... . [if] I became Christian, definitely those things would solve the problem in my life." As other studies have shown, Sabaro's rationale was not uncommon among other late twentieth-century highland Christian converts in India. ${ }^{22}$

Conversion also offered the children of converts the benefit of primary school education. Long before government schools arrived in Soraland, RLDS missionaries from Andhra Pradesh established a small elementary school in a Sora village staffed by Oriya-speaking Hindu and Christian teachers. This school was funded by small fees paid by the Sora parents of the pupils, as well as an annual grant from the American RLDS Church. Within twenty years, graduates of the school would be primary school teachers and school superintendents in local government schools, as well as pastors and non-government organization (NGO) workers in Soraland. A select number of the graduates would also become Naxalites, those Marxist revolutionaries who so vexed the Indian government. ${ }^{23}$ Conversion and education in the mission school, then, held out the promise of socioeconomic upward mobility and helped create alternative sources of authority to the Hindu nation state.

With the dramatic act of spiritual rebirth, Sora converts reinvented their past. Before proselytization, Sora had only loosely identified as Hindu and kept most of the valley Hinduism at arm's length from their animistic, localized religious practices. Post-conversion, they retold the story of their former selves as "idol-worshipping" Hindus, conflating drastically different religious systems into one. In a 2014 oral history, seventy-nine-year-old Sadanga Gamanga referred to his pre-conversion time as "the Hindu times." The elderly Dagu Gamanga likewise related that in the late 1960s, "I called the pastors and the lay teachers to help me to convert from Hindu to Christian." Similarly, Jacob Gamanga told me, "We were in the idol worship" before becoming Christian. When pressed further whether the Sora had been Hindu or something else, he reversed his first statement and responded, "Actually we are not following Hindu worshiper as idol worshipers, but as Sora tribal people we had special things; we used to worship sun, moon, rivers, our forefathers-we worshiped their spirits-and offered cow, water buffalo, chickens." Gamanga further noted, "If anyone would die from our family, remembering her or he, we used to put in long stone [ganuar] also

\footnotetext{
${ }^{21}$ David J. Howlett (unpublished field notes), 7 July 2014, Visakhapatnam, Andhra Pradesh; and Ananda Rao, interview with author, Visakhapatnam, Andhra Pradesh, 5 July 2014.

${ }^{22}$ Kando Sabaro, interview with author, Dariamba, Odisha, 29 June 2014; B. G. Karlsson, Contested Belonging: An Indigenous People's Struggle for Forest and Identity in Sub-Himalayan Bengal (New York: Routledge, 2013), 182; and Barbara M. Boal, The Konds: Human Sacrifice and Religious Change (Warminster: Aris and Phillips, 1982), 194.

${ }^{23}$ Maurice Draper, “School,"(unpublished field notes), Orissa, 23 September 1977, Maurice L. Draper Papers, P118, f277, CCA; Charles D. Neff, “An Oral History Memoir by Charles D. Neff,” interview by E. Keith Henry, transcript, 1980, Oral History Collection, CCA, 106, 109, 112; Naomi Russell, "Created for a Purpose,” Saints' Herald 116, 1 January 1969, 15-16; Sadanga Gamanga, interview, Gumiguda, Odisha, 28 June 2014; T. Daniel Raju, interview, Bhimavarum, Andhra Pradesh, 16 June 2014; Nojun Gomongo, interview, Chadanpur, Odisha, 27 June 2014; and Peter Gomongo, interview, Tumangapadar, Odisha, 24 June 2014.
} 
in the ground, and we used to remember that one." ${ }^{24}$ Like many forms of collective memory, RLDS Sora collective memory created a more-or-less agreed upon narrative about the past that existed in tension with other narratives; in this case, an "official" narrative about an idol-worshiping Hindu past that uneasily fit with stories that the oldest knew about their own lives prior to conversion. ${ }^{25}$

With the reinvention of their past selves as "idol-worshiping Hindus," Christian Sora asserted a sense of temporal separation between their present selves and past selves, a sense of boundary separation that had once primarily been articulated as geographical separation between the Sora hills and the Hindu valleys. This observation helps reframe what some scholars have noted as the propensity of modern evangelical and Pentecostal Christian converts to enact "rituals of rupture," or formal acts that mark themselves off from their former identities. ${ }^{26}$ The Sora I have quoted certainly spoke a language of rupture and even enacted it in ritual form. For example, Sora converts smashed the pots that contained the spirits of their dead relatives, an act which signaled that they had become Christian. ${ }^{27}$ However, when placed against the background of the boundaries of hills and valleys, their language looks more like an extension of these dyadic geographical relationships to a new plane-the temporal. Framed in Scott's terms, the "rupture" of Sora Christian conversion is a "state effect" given force by its comparison with the ever-present valley.

As noted in my introduction, Scott argues that highlands people adopted religious practices that were heterodox from the valley as a strategy to frustrate state-sponsored assimilation. Scott claims that highlanders largely embraced millenarian religions, in contrast to the more staid forms of the "great traditions" (Buddhism and Hinduism) that the valley peoples adopted. Additionally, the highlands people practiced their religion with "millenarian fervor that valley elites [found] more threatening than reassuring." 28 Whatever the fervor with which Sora embraced their new religion, the RLDS Sora practiced a form of Christianity that had relatively little to say about end times or a coming age of perfect peace. While these were topics that traditional American RLDS embraced, the liberalizing American RLDS missionaries, imbibing biblical studies and theological currents from mainline Protestant scholars, never taught those subjects when they preached to Sora gatherings, sticking almost always to texts and teachings in the canonical New Testament gospels that avoided such subjects. American RLDS missionaries also never used traditional RLDS texts, like the Book of Mormon, and to this day RLDS Sora only use the Bible as a sacred text. ${ }^{29}$ RLDS Sora, like the Baptist Sora,

\footnotetext{
${ }^{24}$ Sadanga Gamanga, interview; Dagu Gomongo, interview, Badakua, Odisha, 28 June 2014; and Jacob Gamanga, interview, Mutaguda, Odisha, 22 June 2014. Compare with Vitebsky, Living without the Dead, 14; and Vitebsky, "Stones, Shamans, and Pastors," 119-120.

${ }^{25}$ For a Mormon example, see Stephen C. Taysom, "A Uniform and Common Recollection: Joseph Smith's Legacy, Polygamy, and Public Memory, 1852-2002," in Dimensions of Faith: A Mormon Studies Reader, ed. Stephen C. Taysom (Salt Lake City: Signature, 2011): 178.

${ }^{26}$ Joel Robbins, "On the Paradoxes of Global Pentecostalism and the Perils of Continuity Thinking," Religion 33, no. 3 (2003): 224.

${ }^{27}$ Naomi Russell, "So Much from So Little: A Report on the Growth of the Church in India," Saints Herald 114, 1 January 1967, 9.

${ }^{28}$ Scott, Art of Not Being Governed, 21.

${ }^{29}$ Sumbara Sobor, interview, Gumiguda, Odisha, 23 June 2014; Sadanga Gamanga, interview; and Rao, interview. American RLDS reformers wanted to be part of the ecumenical movement and saw the Book of Mormon as a parochial nineteenth-century American text that did not have the same universality as the Bible. By saying the Book of Mormon was not relevant to the Sora, these leaders also suggested that it was not relevant to the American church if it wanted to be a global church.
} 
had little to say about the Christian afterlife, something that Piers Vitebsky saw as a sign that the Baptist Sora had embraced a cosmology before working out a detailed explanation of that cosmology. ${ }^{30}$ Nonetheless, the Sora's embrace of Christianity was cause enough to engender suspicion from their Hindu valley neighbors. By the late 1960s, the state of Orissa had passed an anticonversion law, one step toward what would later become a "Hindutva" political awakening among the Hindus of the valleys. Tribal Christians, like the Sora converts, were legally suspect by virtue of their new "foreign" religious identity. ${ }^{31}$

Beyond state laws that cast Christianity as a foreign entity, Sora encountered local ideas about the mutability of tribal identity that gave them cause to worry about their status as both Sora and Christian. Limpan Raika recounted his initial unease regarding conversion when he encountered Christianity as a thirty-year-old in 1966: "If I became a Christian, I would become a Dalit or be excommunicated from my people." This was a fear that others voiced, too. Baidi Mandal articulated as much in the opening vignette for this article. However, Limpan Raika came to understand that by becoming Christian, "It was not [that] I was excommunicated from my community, but really we were attaching with God, we became God's people." As conversions progressed from individuals to entire villages, the RLDS Church offered a new structure for Sora identity and a new way of constructing peoplehood. Before conversion, the center for Sora identity was the local village; postconversion, it was the "East India Mission" of the RLDS Church that eventually connected more than eighty villages, much like it had done for Sora in the Sora Baptist Association to the south. ${ }^{32}$ Reflecting upon the change within his village over the past fifty years, Jacob Gamanga, who in 1966 converted at the age of fifteen, remarked, "We feel like one family... . Through this village there are fourteen villages [connected together in a church pali or district]." Gamanga's "one family," of course, was primarily Sora, but at its edges, it also included the Scheduled Caste Telegu missionaries, as well as the white, middle-class American administrators who visited Sora villages, the latter referred to by the Sora as "our foreign friends." 33

\section{Sora Christians and the Controversy over Polygyny}

From 1970 to 1972, neither American administrators nor Telegu missionaries visited the Sora villages, leaving the newly ordained Sora leaders to run the church on their own. Sora leaders whom I interviewed called this era "the silent period." It began when Sora leaders received a letter from the American leaders saying that they should remain as a part of the church and a new minister would be sent to them in the future. Nothing more was heard from the Americans until the end of $1972 .{ }^{34}$ In the interim, the new minister promised in the Americans' letter, the young Ananda Rao, completed a theology degree at Allahabad Bible College, an ecumenical, evangelically-inflected seminary far from Orissa. An extraordinarily charismatic leader from Andhra

\footnotetext{
${ }^{30}$ Vitebsky, "Stones, Shamans, and Pastors," 133.

${ }^{31}$ Chad M. Bauman and James Ponniah, "Christianity and Freedom in India: Colonialism, Communalism, Caste, and Violence," in Christianity and Freedom, vol. 2, Contemporary Perspectives, ed. Allen D. Hertzke and Timothy Samuel Shah (Cambridge: Cambridge University Press, 2013), 228-230; and Laura Dudley Jenkins, Religious Freedom and Mass Conversion in India (Philadelphia: University of Pennsylvania Press, 2019), 136-151.

${ }^{32}$ Vitebsky, "Stones, Shamans, and Pastors," 129.

${ }^{33}$ Limpan Raika, interview, Mutaguda, Odisha, 22 June 2014; and Jacob Gamanga, interview.

${ }^{34}$ Sadanga Gamanga, interview.
} 
Pradesh, Rao had already spent a few months working with G. S. Chawla among the Sora in 1969. In 1970, American leaders promoted Rao to replace the well-liked G. S. Chawla, whose questionable financial practices with church funds had led to his termination as an employee of the RLDS Church. Chawla, a married man, had also begun an affair with a Sora woman, placing the Sora leaders in a compromising position when they addressed a rather contentious issue-traditional Sora polygyny. ${ }^{35}$

In 1972, American administrators put in place a policy whereby a man and his wives could be baptized as church members but could not take more wives into their family after baptism. As will later be seen, the American administrators came to this policy after a great deal of debate among themselves, which then spilled over to congregations and conferences across the United States. On the ground in Soraland, the policy itself, its origin, and its implementation were understood somewhat differently. Sadanga Gamanga was a member of a church committee that ran the Sora church from week to week. He relayed that the local church committee decided in 1968 that any Sora who practiced polygamy would no longer be a member of the church or a minister. The rationale for this ruling was quite simple for Sadanga, "The Bible taught us that there is not polygamy practiced." Whatever the ambiguities of the biblical text on marriage, Sadanga's understanding of its contents was that it brooked no compromise on allowing polygamy, and in this way, he mirrored the understanding of Sora Baptists with whom he undoubtedly had some contact. However, the first Christian in Sadanga's village, Budo Gamanga, had three wives and had served as a lay minister after his 1964 baptism. " "I cried and I prayed for him [Budo]," related Sadanga. "I talked with him, 'Why are you doing these illegal things? This is not good character in the Christian.' And he was not convinced with my advice, because of that he [was] sometimes against me." Budo was an influential leader in the village, and Sadanga decided to eventually leave the hamlet after a year-long conflict with Budo. ${ }^{37}$

As Sadanga relates, the conflict over polygamy raged for three to four years, but in the end, the Sora committee that ran the day-to-day operations of the church regularized the ban on polygamous members. Polygamous men still came to Sunday worship gatherings in their villages, but they were no longer accepted as communing church members or used as ministers in any setting. Notably, these polygamous men included those who had taken multiple wives before their baptism, but had not taken any since: the very people the American leaders had sought to accept in their baptismal policy. Thus, the Sora-implemented policy was noticeably more restrictive than the policy that the American administrators thought they had put in place. When an American administrator, Howard "Bud" Sheehy, finally returned to Soraland in late 1972, months after the American debate on Sora conversions detailed below, he presided over a "church court" that revoked church membership for several polygamous men, including Budo Gamanga. Sheehy wisely allowed local Sora leaders to pronounce local church policy and their judgments against the accused. He simply affirmed the policy and judgments. ${ }^{38}$

\footnotetext{
${ }^{35}$ Sadanga Gamanga, interview; Rao, interview; Raju, interview; Howard "Bud" Sheehy, interview, Independence, Mo., 8 January 2014; and RLDS Presiding Bishopric to B. K. Panigraphy, Independence, Mo., 28 July 1971, Presiding Bishopric Papers, RG28, f53, CCA.

${ }^{36}$ Budo Gamanga was baptized by Junesh Raika two years before Junesh affiliated with the RLDS Church. Birsuna Mandal, "Brief History," 3.

${ }^{37}$ Sadanga Gamanga, interview.

${ }^{38}$ Sadanga Gamanga, interview; and Sheehy, interview.
} 


\section{Remaking the Sora Hills: Government and American Interventions}

Across the 1960s and 1970s, RLDS village churches quickly expanded in Soraland, moving ahead of developments that would further alter the people and the land. Roads and democratic processes of governance began to arrive in Sora villages by 1975 , and with these developments, the Indian nation-state more directly demanded rituals of obeisance from the Sora. Villagers were quick to show that they were loyal citizens. The mission school erected a flagpole around which children performed programs every Independence Day. Children learned how to read and write Oriya in the school, rather than the phoneticized Sora script invented by Canadian missionaries in the 1950s. ${ }^{39}$ In 1984, as Vitebsky notes, Indian Prime Minister Rajiv Gandhi “poured money into local Tribal development, especially for roads and schools . . . and made the panchayat the conduit for this money." 40 Consequently, when Sumbara Raika, an influential RLDS Sora pastor, was elected to the panchayat development council, he held a great deal of local power. ${ }^{41}$ All of these changes pointed to how RLDS Sora were becoming incorporated as citizens of the Hindu valleys. However, the church also provided a new avenue for "citizenship" and connection based upon relationships of affinity outside of the nation-state, perhaps most effectively through the growing presence of RLDS church-sponsored NGOs.

One RLDS NGO in particular, Outreach International, affected Sora villages with its "Participatory Human Development" strategy which was advocated by its president Dennis Laybayan, a Filipino Catholic who worked for the RLDS Church for forty years. This strategy-which was based upon models for community organizing first developed by Saul Alinsky - sought to have villagers identify their collective development goals, have NGO workers train the villagers to effectively advocated for themselves in the maze of the Indian government's bureaucracy, and thus obtain governmentsponsored funding for electricity, elementary schools, or wells. Direct aid from Outreach International came in the form of funding for a nutrition program at the church-sponsored school. Sora leaders and Sora social workers helped distribute this aid, occasionally running afoul of American administrators when they distributed direct aid to other projects, such as funding a youth hostel in Berhampur or the cement for a Sora leader's new house. ${ }^{42}$ Nonetheless, the language of the NGO became a shared language among the Sora village elites and Americans.

The American church also transformed the Sora highlands by branding itself on the landscape. By the 1990s, Sora had begun to obtain funding from the American church to construct church buildings, replacing the small outdoor arbors that many villages used for worship. On the exterior and interior of these buildings, Sora craftsmen painted the American church's logo of a lion, a lamb, and a child, with the word "Peace" below it in English and Sora (written with Oriya script). Pastors carried lectionaries that featured on the back cover a photo of the Independence, Missouri temple, the

\footnotetext{
${ }^{39}$ Birsuna Mandal to author; and Howard S. Sheehy, "India, A Decade of Mission: Part II-East India," Saints Herald 122, 15 January 1975, 81-82.

${ }^{40}$ Vitebsky, Living without the Dead, 177; and "Church Celebrates 25 years in India" Saints Herald 137, May 1990, 207.

41“"Church Celebrates 25 Years in India," Saints Herald 137, May 1990, 207.

${ }^{42}$ Matthew Bolton, Apostle of the Poor: The Life and Work of Missionary and Humanitarian Charles D. Neff (Independence, Mo.: John Whitmer, 2005), 111-114; Eduardo “Toto" Delfin, interview, Cabanatuan City, Philippines, 6 July 2015; Howlett (unpublished field notes), 29 June 2014, Gumiguda, India; Howlett (unpublished field notes), 5 July 2014, Rayagada, India; and Howlett (unpublished field notes), 22 July 2015, Roxas, Philippines.
} 
soaring three hundred-foot tall RLDS headquarters structure. ${ }^{43}$ In select ways, the American plains had moved into the Sora highlands.

\section{Sora Resistance and the Reterritorialization of the Hills}

Despite the incorporation of the church and its affiliations into their society, the Sora resisted other attempts to grid them onto a recognizable American template for RLDS identity. RLDS Sora assiduously maintained forms of church discipline, leadership, and organization that closely resembled the nearby independent Sora Baptist Association, once sponsored by the Canadian Baptists. In 1992, new RLDS American administrators found the Sora priesthood system inadequate compared with the structure of the American priesthood system. ${ }^{44}$ Consequently, the highest Sora church leaders were ordained into RLDS offices like "seventy," "evangelist patriarch," "elder," "priest," and "deacon." On paper, then, Sora had all of the ordained offices of the American church by the early 1990s. However, in practice, Sora simply maintained their older Canadian-Baptist inspired leadership system. At its base, this system had visiting lay teachers who preached sermons every Sunday to village congregations. These teachers were unordained and did not correspond to the RLDS priesthood office of "teacher." Sora lay teachers were supervised by an ordained elder who administered a "pali" of ten or more village congregations. The pali elder, along with an assisting deacon, served as the only authorized individuals to perform the church's sacraments like baptism and communion. All of these Sora individuals were male. ${ }^{45}$ In contrast, a large RLDS congregation in the United States often had a dozen ordained elders who rotated preaching and sacramental duties, and nearly every active adult, male or female, held some kind of priesthood office. ${ }^{46}$ Organizationally, the Sora and American churches had only superficial similarities.

Differences in priestly offices and functions did not mean that the Sora church and the American church were parallel, disconnected entities. Within the social space of the RLDS denomination, Sora and Americans formed functional relationships with each other that in select ways mirrored the client-patron relationship that had once existed between Sora and the people of the valleys. Oriya-speaking Pano-caste bariks had once been the intermediaries between Sora village leaders and the people of the valleys. Sora who could not speak or read Oriya relied upon bariks to sell their crops to the valley peoples, as well as work out loans and land deeds for them. By the late 1970s, the Oriya bariks had begun to disappear as Sora themselves began to read and write Oriya. Nevertheless, Telegu-speaking RLDS missionaries in this same era held roles that hearkened back to these earlier patterns between Sora and the valley peoples, though this time the valley peoples were the Americans. The Telegu missionaries distributed resources from the American church to the Sora and also served as translators between the Americans and Sora, who could not directly talk to each other. One Telegu missionary found that his intermediary role meant that he could profit quite directly from his control of the flow of resources from Americans to Sora. The Telegu missionary used some of the earmarked development funds from the American RLDS to make loans to Sora

\footnotetext{
43"President McMurray Meets with Members in India, Witnesses Opening of Sri Lanka to Church," Saints Herald 144, May 1997, 212; and Howlett (unpublished field notes), 29 June 2014.

${ }^{44}$ Sadanga Gamanga, interview; and James Cable, interview, Independence, Mo., 6 January 2014.

${ }^{45}$ This organization and structure mirrors such arrangements in the Sora Baptist Church. See Vitebsky, Living without the Dead, 174-175.

${ }^{46}$ David J. Howlett and John-Charles Duffy, Mormonism: The Basics (New York: Routledge, 2016), 156.
} 
pastors who became indebted to him. Yet by the 1990s, literate, English-speaking Sora replaced these Telegu missionaries, and Sora leaders could also effectively press back against the decisions and policies of their American administrators, sometimes even forcing changes in administrative leadership. ${ }^{47}$

In 1992, the charismatic Telegu missionary who served as the administrator over the Sora churches, Ananda Rao, was accused by Sora leaders of keeping a mistress in one of their villages. Rao denied the charges. The American administrator for India, Apostle James Cable, not knowing whom to believe, threw his support behind his longtime friend, Rao. "Because he supported Ananda Rao," related Sora deacon Sadanga Gamanga, "Jim Cable was not accepted by area [Sora] people." With this loss of support, higher American administrators decided to transfer both Rao and Cable to new assignments. "If people do not take advice, [it is] definitely difficult for them in [the Sora] church," Sadanga wryly noted. ${ }^{48}$ Masia Raika, a twenty-four-year-old Sora leader, replaced Rao, making him the first Sora RLDS administrator over the region's churches.

Raika represented the new face of the Sora church in India. He had been educated at the RLDS mission school and had never known a time before Christianity came to his village. Unlike previous Sora RLDS leaders, he held local political power, was fluent in English, and enjoyed greater mobility. In the early 1990s, Raika became the first Sora to visit the RLDS World Conference in Independence, Missouri, as well as other leadership conferences in North America and Asia. When American administrators came to visit Sora villages, Raika negotiated safe passage for them with nearby Naxalites, the Maoist insurgents who had begun to operate in the area during the 1990s. As mentioned previously, some of the area Naxalites had once themselves attended the RLDS mission school. Raika ensured that his former classmates, now Naxalites, did not mistake the Americans' rented four-by-four vehicles for police vehicles. ${ }^{49}$ In his position as the leader of the RLDS Church in Soraland, Raika became a skilled intermediary and formidable political broker between the plains and the hills.

At a polity level, Raika successfully pressured his American supervisors to approve new ecclesiastical units to separate Sora churches from nearby Kui (Khanda) RLDS congregations that had begun to spring up in the Orissa highlands in the 1980s. What resulted was the East Orissa Mission (Sora) and the West Orissa Mission (Kui). Raika's lobbying for separate Sora and Kui missions ran contrary to the goals of his American administrative supervisors who hoped the church would unite people beyond lines of tribe and caste. Raika would clash with his American administrators on any number of other issues, including priesthood restructuring and same-sex marriage; the stories of these interactions remain to be detailed elsewhere. Even with the various inter- and intragroup controversies in the 1990s, Raika presided over a growing church, composed of eighty-four village congregations and upward of 16,000 individuals attending weekly services. ${ }^{50}$

From 1964 to 2000 , the hills and valleys around Soraland were radically reshaped, but their topographical outlines still remained. Through conversion to Christianity, Sora maintained practical differences between themselves and their Hindu neighbors in the valleys. In

\footnotetext{
${ }^{47}$ Sadanga Gamanga, interview; and Howlett (unpublished field notes), 7 July 2017.

${ }^{48}$ Sadanga Gamanga, interview.

49"Indian Youth to Attend International Youth Forum," Saints Herald 140, May 1993, 201; Dale Luffman, interview, Independence, Mo., 10 January 2014; and Sheehy, interview.

${ }^{50}$ Birsuna Mandal, Brief History, 6-7; and Amson Mallick to Apostle Andrew Bolton, "Community of Christ, Orissa, India: Mission Case Studies," (report in possession of the author), 10 November $2008,1$.
} 
their new ecclesiastical alliance with an American church, they were able to partially disengage from their patron-client relationships with their valley neighbors, especially around relationships of economic mediation that Christian Sora had characterized as exploitative. Christian Sora also created space between themselves and the traditional Sora whom they had once been; the Christian Sora recast the traditional Sora as "idol-worshipping Hindus," just like the valley people. In this way, Sora constructed a new "hill country" for themselves, creating an ideological break between themselves and the state even while participating in various modernization programs run by NGOs and the government. The Sora's new allies, the American missionaries, also provided new interlocutors with whom they could create separation. In select ways, the Americans had become the new people of the valley (the "state") for the Sora uplanders, generating a mutually beneficial and frustrating relationship. But why would the Americans want to climb the Sora hills in the first place?

\section{The RLDS American Plains and Cosmopolitan Aspirations}

In the middle of the nineteenth century, dissenters from a smattering of Mormon traditions founded the Reorganized Church of Jesus Christ of Latter Day Saints. Unlike their LDS cousins headquartered in Utah, the Midwest-based RLDS forged an identity based on strong opposition to polygamy and their affirmation that the prophet-leader of their church should be a lineal descendant of Joseph Smith. Like the LDS, they embraced the Book of Mormon as scripture, claimed to be a restoration of Christ's New Testament church, declared exclusive sacerdotal and sacramental authority, maintained a complex many-tiered priesthood system, and believed Independence, Missouri would be the site of the New Jerusalem, a city and community that Mormons called Zion. While the LDS affirmed the latter doctrinal point in theory, RLDS affirmed it in practice and made Independence their headquarters, becoming the dominant religious group in the Midwestern town by the early twentieth century. ${ }^{51}$

As a whole, the nineteenth-century RLDS Church stood in less tension with its surrounding society than the LDS Church did. If the LDS Church in the Intermountain West functioned as a nation state in the nineteenth-century, constantly in conflict with the ever-expanding imperial U.S. government, the Midwestern RLDS Church was a garden-variety sect in the midst of other American churches. Yet RLDS leaders were not content to remain a small sect. With $\mathrm{PhDs}$ in sociology and theology from America's best universities, an influential group of mid-twentieth-century RLDS leaders began to drink deep from the modernist paradigm of their day and desired new respectability among America's liberal churches. ${ }^{52}$

By the end of World War II, the RLDS Church had congregations in nations with many English speakers: the United States, the United Kingdom, Canada, Australia, and New Zealand. They also had dozens of congregations in French Polynesia and a few scattered congregations in Western Europe. By 1960, the RLDS Church was already a worldwide church, with a population of around 174,000 . The vast majority of RLDS Church members, however, lived in the middle of the United States. Even still, many RLDS leaders and members emphasized that they were part of a global church, not an American church. To reflect this, the church's largest legislative and worship meeting

\footnotetext{
${ }^{51}$ Roger D. Launius, "Neither Mormon nor Protestant: The Reorganized Church and the Challenge of Identity," in Mormon Identities in Transition, ed. Douglas J. Davies (New York: Cassell, 1996), 52-60; and Howlett and Duffy, Mormonism, 47-48, 132.

${ }^{52}$ David J. Howlett, "The Death and Resurrection of the RLDS Zion: A Case Study in 'Failed Prophecy,' 1930-70," Dialogue: A Journal of Mormon Thought 40, no. 3 (Fall 2007): 115-116.
} 
changed its name from the "General Conference" to the "World Conference" in 1960, and leaders immediately began to refer to the RLDS Church as the "World Church."

\section{RLDS Expansion in Asia and the Missiology of Indigenization}

The desire to be the "World Church" went hand-in-hand with the expansion of the RLDS Church into Asia-first into post-war Japan, then Korea, and then into India. One of the prime architects of this post-war expansion, Charles Neff, went to Japan as a missionary in 1960. As a high-level administrator, Neff was not an ordinary RLDS missionary, for he was ordained to the office of apostle and part of the church's highest administrative group below the church's First Presidency. A Baptist convert to the RLDS Church, thirty-eight-year-old Neff had been charged with overseeing the church in Asia for the next decade. Unlike some of his older colleagues, Neff was not invested in RLDS theology that proclaimed its organization as the one true church and constantly contrasted itself with the LDS Church. Neff had little desire to teach and replicate RLDS priesthood structures in Asia, and he had never had a powerful connection to the Book of Mormon or Doctrine and Covenants, the two distinctly Mormon texts that the RLDS held sacred along with the Bible. Neff felt that these "traditional" RLDS elements were only intelligible within the Midwestern American world of midcentury RLDS members. They made no sense to the Japanese that he encountered on mission and answered few of their needs. ${ }^{54}$

Instead of transplanting the RLDS Church in America to Asia, Neff felt the need for an "indigenization" of the RLDS message. In later reminisces, Neff explained that a missionary planted the seed of the Gospel by introducing Christ to a people. God was already present within any culture, and the work of the missionary was to help people to be sensitive to where God was within their culture. ${ }^{55}$ While Neff later could not pinpoint when he first embraced this notion, the idea of the need for "indigenization" within RLDS missionary work was first formally articulated at a conference in Iowa in 1957, with the most prominent early advocate for it being Japanese-convert Sekine Kisune. ${ }^{56}$ Shortly after that conference, the RLDS apostle Reed Holmes used the concept of indigenization to predict the future shape of the church in India. After the baptism of one Indian convert family, the Gideons, in Delhi in 1958, Holmes predicted that, "the gospel, being universal, will grow in Indian soil as well as American. From the beginning there shall be no colonialism. We hope for the fundamentals of the gospel to be applied to the specific needs and culture of India... . We are hoping that he [Brother Gideon] and others will be able to author materials, applying the essentials of the gospel and flavoring those materials with the cultural heritage which is India." ${ }^{57}$ While Holmes's hopes did not come to fruition with the Gideon family, who shortly thereafter moved to Canada, his sentiments echoed larger assumptions that were being embraced even by sectarian groups like the American-based Assemblies of God in the same era. ${ }^{58}$

\footnotetext{
53“Membership Information," Saints' Herald 118 no. 4, April 1971, 8; and "World Conference," General Conference Bulletin no. 8, April 1960, 95.

${ }^{54} \mathrm{Neff}$, Oral History, 8-9, 62, 205-207.

${ }^{55} \mathrm{Neff}$, Oral History, 186.

${ }^{56}$ Kisuke Sekine, "Interpreting Our Message to the Japanese," Saints' Herald 104, 27 May 1957, 492.

${ }^{57}$ Reed M. Holmes, “The Waters of Yamuna," Saints' Herald 105, 23 June 1958, 585.

${ }^{58}$ Angela Tarango, Choosing the Jesus Way: American Indian Pentecostals and the Fight for the Indigenous Principle (Chapel Hill: University of North Carolina Press, 2014), 36-40.
} 
This last observation points to the fact that "indigenization" in Christian missions has a wider and longer history transcending the RLDS Church. Within the history of Protestant missions, the "indigenous principle" can be traced back to the work of Rufus Anderson, the secretary of the nineteenth-century American Board of Commissioners for Foreign Missions. ${ }^{59}$ However, the RLDS framework for indigenization seems to have been more directly influenced by the liberalizing assumptions of early twentieth-century Protestant missionaries like Daniel Fleming, E. Stanley Jones, and Frank Laubach. Decades before Neff and Sekine, these Protestant missionaries advocated for an indigenous principle that trusted local individuals with leadership roles, decentered Christian exceptionalism, and recognized other cultures as holding wisdom from which the missionary and "sending" culture could learn. ${ }^{60}$ Significantly, Neff would embrace all of these elements as he articulated his understanding of the new RLDS method for missions.

Beyond his advocacy for indigenization, Neff made some stark changes to the ideological message shared by RLDS missionaries. He pared down the RLDS message to two principles, both summations of Jesus's "two great commandments": the "reality of God" and the "worth of all persons." These principles, thought Neff, would be manifest in different cultures in different ways. Furthermore, following the indigenous principle, the primary leaders for the local church needed to be indigenous leaders rather than Western missionaries. ${ }^{61}$ In his dispatches from Japan to the American headquarters, Neff began to articulate these basic principles and ideas. Among the missionaries in Japan, as well as many of the younger employees back at the American RLDS headquarters, Neff's arguments helped authorize a revision of the RLDS tradition as a global church. For conservative American RLDS members, Neff's arguments would be emblematic of a dangerous leftward turn in the 1960s RLDS Church. However, the full impact of Neff's indigenous principle was not felt by the American church after conversions in Japan, but in Soraland.

\section{VIII: American RLDS and Their Sora Polygamy Controversy}

In a small Sora village in 1967, Neff stepped into a pool of water, about to conduct a baptism by immersion with a group of new Sora converts. Neff had first visited Sora villages for a few weeks in 1965, and this was his third time among the Sora people of the region. As the official RLDS administrator for Asia, Neff insisted that Sora and Indian evangelists should take the lead on preaching, articulating theology, and making converts, while he took the role of a visiting representative of the American church. As one who did not know the Sora language, he also relied largely on a few English-speaking former Baptist, non-Sora Indians from Andhra Pradesh to communicate with Sora converts. Still, while on his trips through Soraland, he was often asked to preach in Sora congregations and baptize new members evangelized by others. As Neff baptized a Sora man on his 1967 trip, another man walked into the water and asked for baptism. Neffs Telegu interpreter told him that the man was a polygamist. The man asked for baptism again, but Neff, not knowing what to do, refused. This provoked a

\footnotetext{
${ }^{59}$ William R. Hutchinson, Errand to the World: American Protestant Thought and Foreign Missions (Chicago: University of Chicago Press, 1987), 79-80.

${ }^{60}$ Dana L. Robert, “The First Globalization: The Internationalization of the Protestant Missionary Movement Between the World Wars," International Bulletin of Missionary Research 26, no. 2 (April 2002): 54-58.

${ }^{61}$ Neff, Oral History, 186-187, 203-206.
} 
procedural crisis that Neff brought to the American apostles once he returned home. ${ }^{62}$ What should be the policy on baptizing Sora engaged in polygamy?

For more than a century, RLDS had proclaimed to all who would hear them that they did not practice polygamy and never had, unlike their LDS cousins in Utah who had practiced "plural marriage" until the early twentieth century. Furthermore, RLDS had spilled much ink proclaiming that Joseph Smith, their founder, had nothing to do with polygamy. By the 1960s, RLDS leaders had begun to rethink this rather dubious historical claim in the light of academic scholarship emerging from what was then called "the New Mormon history." Still, the vast majority of RLDS members maintained that Joseph Smith was innocent of introducing polygamy. This belief formed a stout defensive wall in what some historians have called the "Mormon boundary" that RLDS cultivated between themselves and the LDS. ${ }^{63}$

Come the late 1960s, the "Mormon boundary" was beginning to crumble as the American RLDS Church underwent a period of rapid bureaucratic and ideological transformation, creating competing conservative and liberal camps within the church. The liberal faction controlled the church's highest administrative offices and increasingly saw their church as "provincial" and irrelevant in a nation going through a "cultural crisis." To remedy this, RLDS church officials were holding seminars, some taught by mainline Protestant theologians, in which they explored how various theological and procedural matters could be reformed within their church. Other RLDS church officials were attending mainline Protestant seminaries. ${ }^{64}$ The ecumenical Protestant establishment of post-World War II America was finding a welcome home in the RLDS Church. In the process, much of the ideological framework that had defined the RLDS Church as the "one true church" was being left behind, and RLDS conservatives would not let this go uncontested.

Religious studies scholars Dennis Washburn and A. Kevin Reinhart argue that "conversion raises the disturbing possibility that values formerly considered universal and permanent may be in fact relative and contingent." what followed when American administrators, and then the RLDS church as a whole, began to grapple with the question of whether or not polygamous Sora could be admitted into membership. American administrators at first struggled to contextualize Sora polygamy. For this, they read academic works by anthropologists like Verrier Elwin and then wrote to a wide range of churches, inquiring about their policies on conversion. These churches included Adventists, Pentecostals, Methodists, Lutherans, and Baptists. Finally, the apostles in their administrative group developed a policy: Sora men and women who were in polygamous relationships could be baptized on the condition that they would not add more wives to their families after baptism. To insist that polygamous converts divorce could result in serious harm to the women and children affected by the dissolution of the relationship, reasoned the RLDS administrators. ${ }^{66}$ Although church officials did not publicize the new policy, it did not remain an internal

\footnotetext{
${ }^{62}$ Neff, Oral History, 114-115.

${ }^{63}$ Richard P. Howard, “The Mormon-RLDS Boundary, 1852-1991: Walls to Windows," Journal of Mormon History 18, no. 1 (Spring 1992): 1-18.

${ }^{64}$ W. B. "Pat" Spillman, "Taking the Road More Traveled," John Whitmer Historical Association Journal 24 (2004): 135-148.

${ }^{65}$ Washburn and Reinhart, Introduction to Converting Cultures, $\mathrm{xx}$.

${ }^{66}$ RLDS First Presidency, “A Statement on Marriage Relationships in Missions Abroad," August 1967, Charles Neff Papers, P84, F25, CCA; and "Notes from Quorum of Twelve Minutes," 24 March 24, 1967, Charles Neff Papers, P84, F30, CCA.
} 
administrative matter for long. Only five months after the decision, RLDS administrators were answering letters from worried, angry, or curious American members who had heard rumors that the church was baptizing polygamists in India. ${ }^{67}$

By April 1970, delegates openly broached the controversy on the floor of the RLDS World Conference. RLDS administrators attempted to douse the ecclesiastical fire by referring the issue to a committee for a report at the next World Conference, but in the interim, the controversy only burned with greater intensity. RLDS leaders answered letter after letter from American church members who now questioned the policy due to the 1970 conference. In these letters, RLDS leaders tried to provide a fuller context for the policy, as well as persuade the concerned church members of the wisdom of the policy. ${ }^{68}$ Leaders made speeches at congregations and regional conferences to tamp down fears and answer questions, all while they prepared materials for the next confrontation at their biannual World Conference. ${ }^{69}$

At the April 1972 World Conference, various ecclesiastical jurisdictions in the United States brought competing resolutions, all aimed at addressing Sora polygamy. The liberal San Francisco Bay Stake (a "stake" being an RLDS ecclesiastical division like a diocese) brought a proposal titled "Ordinances in World Cultures" that affirmed the policy and ethos of the apostles, citing that the church was called to "proclaim and extend the love of God in Christ to persons in pluralistic societies and among differing and changing life-styles throughout the world" and that "the variety of cultural heritages brings richness and depth to an understanding of the gospel." San Francisco Bay delegates affirmed a cosmopolitan vision that the church would be changed for the better by dialogue with other "cultures." ${ }^{70}$ In contrast, the Center Stake of Zion, the congregations that geographically encircled the RLDS headquarters facility, proposed a much more conservative piece of legislation titled "Baptisms in Primitive Cultures." It affirmed that the "doctrine of Jesus Christ has universal value and application" and then cited lengthy scriptural passages against polygamy, followed by the assertion that "polygamous people in India have already been baptized into the World Church" and stated that "the World Church should refrain from the baptizing of polygamous people."71 A half dozen Sora men who practiced polygamy in fact had been baptized out of several hundred converts by then. The Center Stake resolution used fundamentalist-style proof-texting, and assumed that a universal standard would apply for the church in all places at all times. The writers of the resolution realized quite correctly that their leaders were beginning to operate with different epistemological assumptions.

The conflict posed by the emerging camps prompted the prophet-president to intervene with a revelation issued to the church for its consideration and approval as scripture. This tactic, one used by past RLDS presidents to adopt a policy, was not without risks of widening the division. Nevertheless, RLDS president Wallace W. Smith issued a

\footnotetext{
${ }^{67}$ Duane Couey to Gordon Rydall, Independence, Mo., 7 August 1967, Charles Neff Papers, P84, F25, CCA.

${ }^{68}$ Representative letters may be found in files "Polygamy-Present Day: Letters in Opposition," P84, F26, CCA; "Polygamy-Present Day: Letters in Opposition," P84, F27, CCA; and "Polygamy-Present Day: Verne Deskin Letter,” P84, F29, CCA.

${ }^{69}$ Maurice Draper, speech notes for the address to the Liberty Street Congregation, Independence, Mo., 30 August 1970, Charles Neff Papers, P84, F28, CCA; and "Special Report of the Council of Twelve to the 1972 World Conference," draft, Independence, MO., ca. early 1972, Charles Neff Papers, P84, F30, CCA.

${ }^{70}$ World Conference Bulletin, 9 April 1972, 170.

${ }^{71}$ World Conference Bulletin, 9 April 1972, 168.
} 
revelation that read in part as follows: "Monogamy is the basic principle on which Christian married life is built. Yet, as I have said before, there are also those who are not of this fold to whom the saving grace of the gospel must go. When this is done the church must be willing to bear the burden of their sin, nurturing them in the faith, accepting that degree of repentance which it is possible for them to achieve, looking forward to the day when through patience and love they can be free as a people from the sins of the years of their ignorance." 72 To the dismay of the conservatives, the revelation, whose wording was edited by the prophet's two liberal counselors, affirmed the basic policy originally outlined by Neff. ${ }^{73}$ Like other revelations added to the RLDS Doctrine and Covenants, delegates debated each paragraph of the revelation in smaller "quorum groups" and reported back to the larger conference. Many quorum groups, especially those composed of lower-ranking priesthood members, vociferously disagreed on the revelation. When the conference as a whole finally voted on the revelation by voice vote, the chair noted that the revelation passed with a significant minority vote against it. $^{74}$

Conservatives saw Smith's revelation about Sora polygamy as a relativization of eternal truths and principles. While the 1972 conference was still in session, a group of "some concerned high priests" circulated a pamphlet of which the first line queried in all capital letters: "WHAT COULD (OR SHOULD) HAVE BEEN DONE AMONG THE SORA PEOPLE IN INDIA, INSTEAD OF AUTHORIZING THE BAPTISM OF MEN WHO ARE NOW, AND WHO EXPECT TO CONTINUE TO LIVE IN SEXUAL RELATIONS WITH TWO WIVES, SERVING THESE POLYGAMISTS THE SACRAMENT?" The document consisted of rhetorical questions, followed by RLDS scriptures. The authors rhetorically asked: "Is God a changeable God? Does he now approve of two wives?" and "Is the doctrine of God and Christ an American RLDS Culture?" The writers answered these questions with a resounding no. ${ }^{75}$ Two years later, Richard Price, a leading RLDS conservative and self-described "fundamentalist," self-published a widely circulated book that critiqued the liberal turn in RLDS theology and policy. In one section, he wrote, "Members of the Church of Jesus Christ had fought polygamy with fervor for over one hundred years. . . . But to the surprise of all the Restorationists [RLDS conservatives], the New Positionists [RLDS liberals] throughout the Church took up the cry that to deprive the Sora of polygamy would be wrong-the American saints were only trying to force 'American culture' upon them. The New Positionists apparently do not know that monogamy is God's culture, not America's."76 Even if conservative writers like Price missed the nuances of the polygamy policy, they understood that the policy directly questioned the foundations of their own emerging fundamentalist framework. Conservatives were devouring Protestant fundamentalist writers, a truly new development among RLDS, just as liberals, like Neff and his allies, were reading liberal

\footnotetext{
${ }^{72}$ Doctrine and Covenants (RLDS) 150:10a-b.

${ }^{73}$ Maurice L. Draper, “An Oral History Memoir by Maurice L. Draper,” interview by L. D. Harsin, transcript, 24 September 1980, Oral History Collection, 360-362, CCA.

74"Official Minutes of the Business Session, Friday, April 14, 1972," World Conference Bulletin, 15 April 1972, 268.

75"What could (or should) have been done among the Sora people in India," (ca. April 1972), Charles Neff Papers, P84, F30, CCA.

${ }^{76}$ Richard Price, The Saints at the Crossroads (Independence, Mo.: Price, 1974), 206-207. Price distributed more than 10,000 copies of the first edition of his book and ultimately printed two more editions.
} 
ecumenical Protestants. ${ }^{77}$ Taking a step back, the conflict over Sora polygamy could be read as a skirmish in a much larger war that rendered individual American denominations along new liberal-conservative fault lines after the 1960 s. $^{78}$

\section{American Conversions and the Sora as Rhetorical Example for Reform}

As the 1970s continued and opposing factions found new areas of disagreement, liberal RLDS administrators occasionally looked to Sora as part of their process of solving theological problems close at hand. For example, RLDS first counselor to the president Maurice Draper took a leave of absence from his job in 1976 to complete a PhD in sociology. As his dissertation topic, he analyzed the process of international growth within the RLDS Church after World War II, a process that he had greatly helped to shape. To complete his dissertation, he conducted six months of ethnographic research across the world, including a weeklong visit to the Sora village of Antarba. While there, Draper related that he "had a very strange spiritual impression that life in Antarba could very well be a Zionic expression for those people in that primitive village in India, in terms of the same human values as those in the most sophisticated concept of an industrialized Zion in an industrial Western nation. But this meant [he] had to think of it in different terms as far as the details of the forms and the structures and the relationships are concerned." 79

The traditional American RLDS concept of "Zion" was that of one central gathered community located in Independence, Missouri. The traditional Zion would be of "one heart and one mind," without any poor, awaiting the second coming of Jesus who would descend to meet it with the heavenly New Jerusalem. Draper and others were advocates for a broadened, nongeographical concept of Zion that could be present anywhere rather than just among a gathered remnant in Missouri. ${ }^{80}$ In his one week of observations in Antarba, Draper idealized the village as an expression of this new concept of Zion, and, quite naturally, confirmed for himself a theological point that he already believed.

By the mid-1970s, editors for the official RLDS magazine, the Saints Herald, began to publish articles that emphasized reciprocity in giving and receiving between Americans and Sora. "The teacher, the doctor, the minister, and the tribal leader all work and share together," wrote the American administrator Bud Sheehy. These individuals, according to Sheehy, overcame "language, social, educational, and even religious barriers in a ministry of witness which is deeply touched by the Spirit of Christ." ${ }^{81}$ Frances Neff, the wife of Charles Neff, also reflected on her experiences in India, relating several anecdotes about Sora hospitality. She rapturously ventured, "My personal affirmation is that receiving their freely given, spontaneous love is of such inestimable value that I cannot imagine the barrenness which would be mine if such opportunity to be involved with many cultures beyond our own did not

\footnotetext{
${ }^{77}$ Adam Brasich, "Saints at the Crossroads: Richard Price, Edgar Bundy, and Ecumenism in Cold War America," John Whitmer Historical Association Journal 37, no. 2 (Fall/Winter 2017): 147-174.

${ }^{78}$ Robert Wuthnow, The Restructuring of American Religion: Society and Faith Since World War II (Princeton, N.J.: Princeton University Press, 1988), 133; and Mark Chaves, “The Symbolic Significance of Women's Ordination," Journal of Religion 77, no. 1 (January 1997): 111-114.

${ }^{79}$ Draper, “Oral History,” 568-569.

${ }^{80}$ Paul A. Wellington, ed., Readings on the Concept of Zion (Independence, Mo.: Herald), 30-35, 114$123,132$.

${ }^{81}$ Sheehy, "India, A Decade of Mission," 83.
} 
continue." ${ }^{82}$ Neff and Sheehy wrote, in part, to respond to conservative church members who wondered whether the church should have ever gone to India, given the controversy surrounding Sora polygamy and baptisms. In their role as apologists for world missions, Neff and Sheehy reflected the cosmopolitan aspirations of RLDS members who imagined themselves as world citizens, giving and receiving, learning and sharing, with a worldwide fellowship that transcended various culturally constructed barriers.

RLDS liberals continued a wide-ranging reform program within their own church in the early 1980s, advocating for the ordination of women and greater ecumenical relations with other churches. After passage of a revelation authorizing women's ordination in 1984, they also started construction on a three hundred-foot tall temple in Independence. Unlike the millenarian vision of RLDS conservatives who thought a temple would herald the Second Coming of Christ, RLDS leaders argued it would be dedicated for the "pursuit of peace" and "for reconciliation and for healing of the spirit." Conservatives, in turn, flatly rejected women's ordination and rejected the temple, an expensive project that they saw as dedicated for the wrong reasons and authorized by a man, Wallace B. Smith, who they now called a fallen prophet. An open schism now broke out in the RLDS Church. ${ }^{84}$

RLDS fundamentalists, however, were not the only critics of the proposed temple. At the 1982 World Conference, Charles Neff, now President of the Council of Twelve Apostles, proposed that $\$ 200,000$ of the funds slated for the proposed temple be reappropriated to "programs of evangelism throughout the international church, with particular emphasis on education and training for National [indigenous] Church leaders, the development of creative strategies of evangelism, and the support systems to enhance the possibility of success in growth and expansion." When he spoke to his motion, Neff wondered rhetorically, "What will be the relationship of a building in Independence and the program of Temple ministry here to the church in Zaire and China and Australia and Norway?" The building would cost tens of millions of dollars. A temple that truly reflected a World Church would not be "of concrete and steel" but a "hogan or a thatched roof assembly hall or some other simple edifice." 85 While not naming the Sora in particular, Neff used a generalized indigenous "other" to make his point against the new temple. Neff opposed the temple because he saw it as a move backward to the RLDS past where Independence was the eschatological capital of the world, quite literally the "center place" in RLDS terms. Neff s criticism placed him at odds with the church's First Presidency who were preparing to pragmatically push through women's ordination at the 1984 conference with the promise of building the temple. ${ }^{86}$

Responding to critics on the right and the left, RLDS leaders promoted the envisioned temple as a structure that would benefit the entire denomination, not just the American church. RLDS First Presidency Counselor Howard S. "Bud" Sheehy, himself the administrator over India in the 1970s, returned to the Sora villages in 1988 while on a tour of Asia. The official RLDS magazine covered the visit to the villages. "President Sheehy talked about the ministry of Christ as healer,

\footnotetext{
${ }^{82}$ Frances Neff, “No Longer Strangers," Saints Herald 122, February 1975, 100.

${ }^{83}$ Doctrine and Covenants (RLDS) 156: 5a.

${ }^{84}$ David J. Howlett, Kirtland Temple: The Biography of a Shared Mormon Sacred Space (Urbana: University of Illinois Press, 2014), 97-98.

${ }^{85}$ A Transcript of the Legislative Session of the 1982 World Conference (Independence, Mo.: The Office of the First Presidency, 1982), 211.

${ }^{86}$ Bolton, Apostle of the Poor, 128-132.
} 
reconciler, restorer of life, maker of peace," reported Jim Cable, the current American administrator for India who had accompanied Sheehy. "There were heads nodding in agreement when he told them that is what the Temple will be in the midst of the world. The people could see the Temple as a resource in the life of the church and a benefit to the people of India." 87 Reading between the lines, the people who needed to be convinced that the temple would be a "resource in the life of the church" were not Sora villagers but Americans in the United States, like Neff on the left and members on the right, who would be asked to fund construction of the sixty-million-dollar structure.

Church leaders like Sheehy had reason to worry. In the period between 1984 and 1994, the RLDS Church lost half of its tithing, middle-class American members, some drifting into inactivity and some leaving the church for the Restoration Branches movement, a protest movement. Fundamentalists like the publisher Richard Price called for like-minded RLDS to separate into independent congregations, and at their height, perhaps 10,000 people followed Price's advice to form independent "Restoration branches." Nearly all who joined this Restoration Branches movement had been in tithing RLDS families. ${ }^{88}$ While the RLDS Church paid in full for the temple before its 1994 dedication, the previous thirty years-dubbed by some scholars as the "RLDS Reformation" or "RLDS Vatican II" - had cost the church dearly in terms of active members and resources. ${ }^{89}$

\section{American RLDS and the Reterritorialization of the Valley}

By the 1990s, American RLDS leaders had enshrined a narrative about their recent past that attributed the period of rapid change to the church's expansion into Asia after World War II. In the spring of 1997, the new RLDS prophet-president Grant McMurray, the first non-Smith prophet, spent a week dedicating new church buildings in Sora villages that the American church had partnered to fund. ${ }^{90}$ After his return to the United States, he was interviewed for the American church's magazine, where he reflected on how the church in Asia had changed the church as a whole. McMurray claimed that expansion of the church into Asia "pressed us to examine the most foundational, universal principles of the faith." Before the 1960s, the RLDS Church "had been rather parochial in its outlook," observed McMurray. "Our emphasis was strongly related to a desire to stress how we were different from the mainline Christians denominations and from the Utah Mormons." With the church's expansion into Asia, McMurray reported:

We unexpectedly found ourselves in cultures where those were extremely insignificant questions. Instead, what we had to do was to positively articulate the central

\footnotetext{
87“Apostle Cable Reports on Ministry in India," Saints Herald 135, January 1988, 31.

${ }^{88}$ Beyond the Restoration Branches movement, there were very small individual sects that were organized that did not affiliate with the Restoration Branches movement. However, they all were parts of a conservative RLDS "Restorationist" milieu, as I explain David J. Howlett, "The Restoration Branches Movement: Bodily Boundaries and Bodily Crossings," in Scattering the Saints: Schism within Mormonism, ed. Newell G. Bringhurst and John C. Hamer (Independence, Mo.: John Whitmer, 2007), 315-330. See also George N. Walton, "Sect to Denomination: Counting the Progress of the RLDS Reformation," John Whitmer Historical Association Journal 18 (1998): 50, 58.

${ }^{89}$ Bolton, Apostle of the Poor, 47; and Larry W. Conrad and Paul Shupe, "An RLDS Reformation? Constructing the Task of RLDS Theology," Dialogue 18, no. 2 (Summer 1985): 92.

90"President McMurray Meets with Members in India," 212.
} 
principles of the Christian faith, rather than to dwell on the differences.... Out of that, I believe, we learned how to be able to articulate and experience the giving and receiving principle at the heart of the gospel-of recognizing that we have something valuable to share with other cultures but we also have some things to learn and much enrichment to experience. ${ }^{91}$

With these sentiments, McMurray articulated a cosmopolitan vision for being a global church. Even so, the "we" mentioned in his interview was still decidedly an American church that was changing and, he felt, needed to change more.

In many ways, McMurray's story of cultural exchange between the American church and other "cultures" was simply an updated statement of the 1960s vision of RLDS missionaries who believed, even before they went into India, that such an exchange was possible. In short, they were not simply transformed by their experiences in India. They were also looking for transforming experiences. Consequently, they constructed a "conversion" narrative about change within the RLDS church that fit their reformist orientation. That these 1960s American missionaries had done this was lost on McMurray, who himself had traveled to Soraland and been interpellated by the missionaries' now long-established missiological ideology of cultural exchange. McMurray, like so many converts, articulated a narrative whose conventions and experiences were already set for him.

If we take a broad view of the plains in relation to the highlands, we see that the Sora became a key example in the arguments that American RLDS leaders created to reform their own church in the United States. Whether emphasizing the Book of Mormon as a "parochial American text," rethinking their concept of "Zion," or justifying the construction of the American temple dedicated to "the pursuit of peace," American RLDS leaders found in their imaginings of the Sora church an example to justify the localized changes they desired. While their reform program proved controversial and resulted in a large ecclesiastical schism, the remaining American church, 155,000 strong in the mid-1990s, largely embraced the revisionist paradigm, even voting in 2000 to rebrand their denomination with a new name, Community of Christ. ${ }^{92}$ Thus, if conversion describes individual, group, and organizational transformations, Sora conversions in India became instrumental for mass conversions in America.

\section{Hills and Valleys in a Global Denomination}

Denominations can climb hills insofar as they embrace many of the goals of their highland converts, and provided that they become the new patrons to the system of disrupted relationships between the hills and the valleys wrought by globalization. Denominational centers engage in these relationships with the hills for their own internal reasons; in the case of the American RLDS, it was to reform themselves at home. In turn, the people of the hills, with the patronage of the denominational centers, mitigate some of the flattening effects of their incorporation into the nation state (for instance, the Hindutva-dominated Indian nation state). The net result is that the hills and the valleys, while starting out as simply referents to contiguous geographical features, are

\footnotetext{
${ }^{91}$ Jim Cable, "Our International Evangelistic Calling: President McMurray Ponders Sri Lanka and India Journey," Saints Herald 144, June 1997, 226.

${ }^{92}$ Walton, "Sect to Denomination," 40; and Mark A. Scherer, The Journey of a People: The Era of Worldwide Community, 1946 to 2015 (Independence, Mo.: Community of Christ Seminary Press, 2016), 513-517.
} 
also transformed. By 2000, the Sora still by and large inhabited the villages of the Eastern Ghats, but the valleys to which they responded included both the Hindutva plains and the American Midwest half a world away. Thus, in the latter case, Sora and Americans enacted a deterritorialization and subsequent reterritorialization of hills and valleys. In a world in which the local and the global intersected, a new spatial configuration became possible, one that "create[d] or re-establish[ed] connections with other meaningful spheres across space and time, beyond the confines of the purely 'local," to quote anthropologist David Garbin in his observations of contemporary diasporic communities. ${ }^{93}$ The Sora, of course, were not a diasporic community, but the point is that they need not be one to have enacted a reterritorialization of hills and valleys in a globalized world.

Parts of my arguments find significant resonances with the findings of scholars who have studied Christian conversions and late twentieth-century highland groups. For example, Bengt Karlsson has argued that Rabha tribal people in West Bengal converted to Christianity as an act of maintaining boundaries between themselves and other groups. ${ }^{94}$ The Christianity to which the Rabha converted, I should note, was Baptist and adapted in significant ways to localized concerns, thereby allowing the religion to have staying power. Conversely, churches that were much less adaptive to local concerns made few converts among the highland peoples in late twentieth-century India. Some denominations, while committed to global evangelism, did not even attempt to do so. The RLDS Church's ecclesiastical cousin, the LDS Church, also entered India in the 1960s, but it evangelized almost exclusively among urban middle-class Indians who were already Christian. ${ }^{95}$ The LDS Church pursued a strategy of aggressive cultural homogenization in this era, standardizing everything in its global congregations from the lessons taught on any given Sunday, to the clothing worn at church, to the architecture of church buildings. ${ }^{96}$ With such a program guiding the LDS Church's global expansion, it is hard to imagine that LDS missionaries and administrators would have tolerated the localized, Baptist-like, tribally based Christianity practiced by the RLDS Sora. Another church committed to global evangelism, the Seventh-day Adventists, expanded rapidly among the Rabha in the 1980s, just as the Baptists had done. However, Rabha Adventist churches were virtually empty by the 1990s, in part due to the Adventist denomination's inability to integrate local dietary concerns and its insistence on members worshiping with people across lines of tribe and caste. ${ }^{97}$ Denominations that cannot adapt to local concerns, it seems, do not climb hills, or if they do so, they do not stay in the hills for long.

What of my arguments about the American RLDS? Have any other groups attempted to climb hills to reform themselves at home? This may in fact be the overarching story of the effects of Protestant missions on twentieth-century American culture. Historian David Hollinger has argued as much, stating that in the early twentieth century, American Protestant missionaries from ecumenical Protestant churches left the

\footnotetext{
${ }^{93}$ David Garbin, "Regrounding the Sacred: Transnational Religion, Place Making and the Politics of Diaspora among the Congolese in London and Atlanta," Global Networks 14, no. 3 (2014): 364-365.

${ }^{94}$ Karlsson, Contested Belonging, 152-154.

${ }^{95}$ Taunalyn F. Rutherford, “The Internationalization of Mormonism: Indications from India," in Out of Obscurity: Mormonism since 1945, ed. Patrick Q. Mason and John G. Turner (New York: Oxford University Press, 2016), 46-47.

${ }^{96}$ Matthew Bowman, The Mormon People: The Making of an American Faith (New York: Random House, 2012), 194-197; and Howlett and Duffy, Mormonism, 156-162.

${ }^{97}$ Karlsson, Contested Belonging, 174-176.
} 
United States to change the world but returned to change the United States instead, participating in the liberalization of American culture along more cosmopolitan lines. Hollinger calls this the "boomerang effect." 98 I have shown here how the boomerang was thrown a second time to redound with similar, though more focused, effects upon the policies and ideologies of the American RLDS church.

Of course, the changes that I have noted among the Sora RLDS and the American RLDS could be read as fitting into recognizable narratives about social change limited to India or to the United States, that is, two stories that do not intersect. The Sora could be seen as embracing a new form of "incivility" that pervades postcolonial village India where the lines of difference have been redrawn from lines based upon caste and tribe to increasingly hardened lines based upon religion. ${ }^{99}$ Similarly, the Sora's experiences with Christianization could be read, as Vitebsky does, as a vehicle for the transition from an "indirect feudal relationship with local rajas to a relationship of direct participation in the democratic nation state." 100 The RLDS Americans' story could then be read as the narrative of a religious group transitioning from a sect to a denomination or participating in the restructuring of American religion along a liberal/conservative axis. Such observations surely help make sense of the experiences of both groups analyzed here.

Still, such separate accounts fail to see that in a late twentieth-century globalized world, village India was involved with more than just the Indian nation state, and American denominations were involved with more than localized American culture war concerns. True enough, Sora converts in eastern India and American converts in the Midwest instrumentalized their interactions with each other for their own localized ends. Yet, if viewed through James C. Scott's glasses, these interactions reveal an extension of a much longer story of hills and valleys, non-state and state spaces. Thus, RLDS conversions in the Sora hills and on the American plains created a surprising afterlife for the hills and valleys of upland Asia, all within the space of a global Christian denomination.

Acknowledgments. The author wishes to thank Eliza Kent, Pinky Hota, Matthew Bolton, Briana Wong, Andy Rotman, and Christopher Jones for their insightful comments on earlier versions of this essay.

\footnotetext{
${ }^{98}$ David A. Hollinger, Protestants Abroad: How Missionaries Tried to Change the World But Changed America (Princeton, New Jersey: Princeton University Press, 2018), 2.

${ }^{99}$ Edward Simpson, Alice Tilche, Tommaso Sbriccoli, Patricia Jeffery, and Tina Otten, “A Brief History of Incivility in Rural Postcolonial India: Caste, Religion, and Anthropology," Comparative Studies in Society and History 60, no. 1 (January 2018): 61.

${ }^{100}$ Piers Vitebsky, “The Sora 'Tribe'-Animist, Hindu, Christian," online supplement to Living without the Dead, 36, http://www.press.uchicago.edu/sites/Vitebsky.
}

Cite this article: Howlett, David J. "Why Denominations Can Climb Hills: RLDS Conversions in Highland Tribal India and Midwestern America, 1964-2000.” Church History 89, no. 3 (September 2020): 633-658. https://doi.org/10.1017/S000964072000133X. 